\title{
An Unexpected Diagnosis of COVID-19 in a Trauma Patient
}

\author{
Bir Travma Hastasında Beklenmeyen COVID-19 Tanısı
}

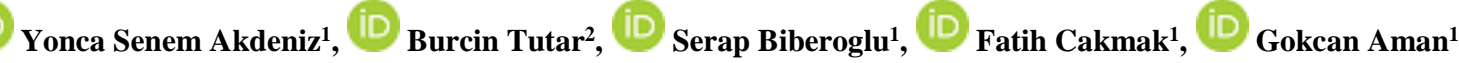
1-Istanbul University-Cerrahpasa, Cerrahpasa Medical Faculty, Department of Emergency Medicine, Istanbul, Turkey. 2- Acibadem Maslak Hospital, Department of Radiology, Istanbul, Turkey.
\end{abstract}

\begin{abstract}
At the end of December 2019, a fast-spreading outbreak had started due to a novel coronavirus in Wuhan city of Hubei, China. At first, patients who do not meet the disease's criteria were accepted without COVID19 but later we noticed that even these patients may have the disease. So, during the pandemic period, every patient must be assumed to have the disease and necessary preventive measures must be taken. In this case, we unexpectedly observed COVID-19 in an old patient who admitted to the emergency department with trauma.

ÖZET

Çin'in Hubei bölgesindeki Wuhan şehrinde 2019 Aralık ayl sonunda hızl bir şekilde yayllan bir salgin başladı. Başlangıçta hastalık kriterlerini karşılamayan hastalarda COVID-19 olmadığ kabul edildi ama daha sonra bu hastalarda bile COVID-19 olabileceğini fark edildi. Yani pandemi dönemi boyunca her hastada COVID-19 olabileceği varsayllmal ve gerekli koruyucu önlemler alınmalıdır. Bu vakamızda, acil servise travma nedeniyle başvuran yaşl bir hastada beklenmedik bir șekilde COVID-19 tespit ettik.
\end{abstract}

Keywords:

Trauma,

Emergency,

COVID-19.

Anahtar Kelimeler:
Travma,
Acil,
COVID-19.

\section{INTRODUCTION}

At the end of December 2019, a fast-spreading outbreak had started due to a novel coronavirus in Wuhan city of Hubei, China (1). The World Health Organization (WHO) declared this epidemic as a pandemic and an emergency around the World on 30 January 2020 and a real-time situation report declaration had begun (2). The virus is named as Severe Acute Respiratory Syndrome Coronavirus-2 (SARS-CoV-2) and the disease as COVID-19 disease (3). At first, patients who do not meet the disease's criteria were accepted without COVID-19 but later we noticed that even these patients could have the disease.

\section{CASE}

A 92-year-old man presented with craniocervical trauma due to a fall from stairs to the emergency department. He had a history of lung carcinoma, and he was under radiotherapy. Also, he had hypertension and diabetes type 2 as underlying diseases. He had no history of travel abroad and said that he didn't accept visitors at home because of his health condition. His respiratory rate was 28/per minute and SPO2 94\% and, had no fever or newly emerging complain of cough, sputum, fever, or shortness of breath. We thought that his hypoxia is chronic due to carcinoma so at first, we did not suspect COVID-19. We planned and neck computed tomography (CT) scan. But the patient admitted that his dyspnea slightly increased for a few days and his arterial blood analysis showed respiratory alkalosis so to rule out pulmonary embolism we also performed a contrastenhanced chest CT scan. CT showed a non-deplaced corpus fracture of the second cervical vertebrae and bilateral lung consolidations (Figures 1 and 2). According to CT findings, the patient had a diagnosis of COVID-19. For the cervical fracture, only a Philadelphia collar is suggested by the neurosurgeon. We provided a 4 liter/min nasal oxygen supply. First Reverse transcription-polymerase chain reaction (RTPCR) assay from swab sample for COVID-19 resulted negatively after six days (due to excess of cases). The second (tenth day) and third (thirteenth day) RT-PCR tests were positive. For COVID-19 treatment the patient took hydroxychloroquine, oseltamivir, ritonavir/lopinavir, favipiravir, antibiotics, and enoxaparin sodium further clinical, laboratory, and treatment details are summarized in table 1and 2. The patient's treatment in the hospital took 15 days. For the last three days, he was intubated in the intensive care unit (ICU) but he could not be survived.

\section{DISCUSSION}

According to data from China, COVID-19 disease has nonspecific clinical and laboratory manifestations, so epidemiological features like the history of close contact with COVID-19 positive cases or presenting in pandemic areas are very important for suspicion and diagnosis (4). Our case had no history of close contact or being in pandemic areas. 
Table 1: Clinical and Treatment Features

\begin{tabular}{|c|c|c|c|c|c|}
\hline Days & Day 1 & Day 3 & Day 5 & Day 11 & Day 13 \\
\hline Condition & Moderate & Moderate-severe & Moderate-severe & Critical & Critical \\
\hline Oxygen & 4 liter/min nasal & 4 liter/min nasal & 6 liter/min mask & $\begin{array}{l}10 \text { liter/min } \\
\text { (rebreathing mask) }\end{array}$ & $\begin{array}{l}\text { 10-12 liter/min } \\
\text { (rebreathing mask) }\end{array}$ \\
\hline $\mathrm{SO}_{2} \%$ & $93-94 \%$ & $91-92 \%$ & $90-91 \%$ & $88-90 \%$ & $84-85 \%$ \\
\hline \multirow{4}{*}{ Treatment } & $\begin{array}{l}\text { Hydroxychloroquine } \\
\text { (2x } 400 \mathrm{mg} / \text { first day } \\
\text { then } 2 \times 200 \mathrm{mg} / 10 \\
\text { days) }\end{array}$ & $\begin{array}{l}\text { Piperacillin 0,5 } \\
\text { g/Tazobactam } 4 \text { g } \\
\text { (3x1/13 days) }\end{array}$ & \multirow{4}{*}{$\begin{array}{l}\text { Ritonavir } 50 \mathrm{mg} / \\
\text { Lopinavir } 200 \mathrm{mg} \\
\text { (2x2/10 days) }\end{array}$} & \multirow{4}{*}{$\begin{array}{l}\text { Favipiravir (2x1600 } \\
\text { mg /first day then } \\
\text { 2x600 mg } 4 \text { days) }\end{array}$} & \multirow{4}{*}{$\begin{array}{l}\text { Intubation } \\
\text { Mechanical Ventilation } \\
\text { (ICU) } \\
\text { FiO2:80\% } \\
\text { PaO2:82 } \\
\text { P/F: } 110\end{array}$} \\
\hline & $\begin{array}{l}\text { Azithromycin (2x250 } \\
\text { mg/first day then } \\
\text { 1x250 mg/4 days) }\end{array}$ & $\begin{array}{l}\text { Enoxaparin sodium } \\
0,6 \mathrm{mg} 1 \times 1(13 \\
\text { days) }\end{array}$ & & & \\
\hline & $\begin{array}{l}\text { Oseltamivir (2x75 } \\
\text { mg/5 days) }\end{array}$ & $\begin{array}{l}\text { Ceftriaxone } 1 \mathrm{x} 1 \mathrm{gr} \\
\text { (stop) }\end{array}$ & & & \\
\hline & $\begin{array}{l}\text { Ceftriaxone } 1 \mathrm{x} 1 \text { gr ( } 2 \\
\text { days) }\end{array}$ & & & & \\
\hline
\end{tabular}

Table 2: Laboratory values

\begin{tabular}{|c|c|c|c|c|c|}
\hline & Day 1 & Day 3 & Day 5 & Day 11 & Day 13 \\
\hline White Blood Cell count/per mm ${ }^{3}$ & 9800 & 9700 & 11100 & 8500 & 8600 \\
\hline Neutrophils & 7300 & 8000 & 9300 & 8100 & 7800 \\
\hline Lymphocytes & 500 & 500 & 500 & 200 & 300 \\
\hline Monocytes & 900 & 1200 & 800 & 200 & 400 \\
\hline Platelet Count /per $\mathrm{mm}^{3}$ & 240.100 & 236.000 & 383.000 & 459.200 & 508.200 \\
\hline Hemoglobin (g/dl) & 11.4 & 11.2 & 10.5 & 10 & 9.8 \\
\hline Albumin (g/dl) & 3.43 & 3.22 & 2.94 & 2.83 & 2.45 \\
\hline Alanine Aminotransferase (U/l) & 14.4 & 16.4 & 46.4 & 37.4 & 33.6 \\
\hline Aspartate Aminotransferase (U/l) & 24.9 & 23.2 & 49.5 & 52 & 51 \\
\hline Lactic dehydrogenase (U/l) & 219 & 186 & 209 & 236 & 350 \\
\hline Creatinine $(\mu \mathrm{mol} / \mathrm{l})$ & 87 & 87 & 102 & 93 & 100 \\
\hline Creatinine Kinase (U/l) & 149 & 263 & 444 & 595 & 522 \\
\hline $\operatorname{EGFR~}\left(\mathrm{ml} / \mathrm{min} / 1,73 \mathrm{~m}^{2}\right)$ & 76 & 76 & 63 & 70 & 64 \\
\hline Troponin T (ng/ml) & 0.024 & 0.034 & 0.029 & 0.041 & 0.047 \\
\hline INR (U/liter) & 1.12 & 1.19 & 1.25 & 1.28 & 1.22 \\
\hline Prothrombin Time (sec) & 14.4 & 14.3 & 15 & 14.8 & 14.3 \\
\hline Fibrinogen (g/l) & 576 & 576 & 576 & 374 & 346 \\
\hline D-dimer $(\mu \mathrm{g} / \mathrm{ml})$ & 5.15 & 5.48 & 8.74 & 6.64 & 5.95 \\
\hline Serum Ferritin $(\mu \mathrm{g} / \mathrm{l})$ & 301 & 269 & 310 & 424 & 475 \\
\hline Procalcitonin (ng/ml) & - & 0.427 & 0.148 & 0.15 & 0.289 \\
\hline C-reactive protein (mg/dl) & 303 & 260 & 191 & 188 & 153 \\
\hline
\end{tabular}

The most common symptoms at the admission are fever (83\%), cough (82\%), and shortness of breath (31\%) (5). Our patient symptoms were indistinguishable due to his underlying diseases, so it was hard to suspect from COVID-19.

A descriptive study made in Wuhan showed that COVID-19 pneumonia has typical CT findings even the patient is asymptomatic besides CT imaging could be very useful for early diagnosis if combined with clinical and laboratory assessment (6). These typical findings are nodular and peripheral multifocal ground-glass opacities which usually start from the posterior or lower part of the lung and air bubble, reversed halo or atoll sign and pneumothorax can be seen (7). Our case had bilaterally consolidations at lower lung lobes and diagnosed through CT appearance.

In a Chinese study, initial RT-PCR from swab samples had lower sensitivity to diagnose COVID-19 compared with CT like in our case (8).
According to underlying diseases, the case fatality rate was $10.5 \%$ in cardiovascular disease, $7.3 \%$ for diabetes, $6.3 \%$ for chronic respiratory disease, $6.0 \%$ for hypertension, and $5.6 \%$ for cancer (9). Our case had three of these comorbidities that could have additional influence on his death.

Lymphopenia is very common and could be related to severe clinical state and mortality (10). D-dimer levels are significantly higher especially in severe and mortal disease, and initial levels higher than $2.0 \mu \mathrm{g} / \mathrm{mL}$ could predict bad prognosis (11). Our patients had lymphopenia and a high D-dimer level so they might be the cause of lung pathologies and mortality. According to the results of an open-label non-randomized trial, hydroxychloroquine was significantly effective through viral load reduction, and also reduce average viral carriage time, besides azithromycin combination enhance this effect (12).

But we must be precautious against the prolongation of QT interval and fatal arrhythmias. 


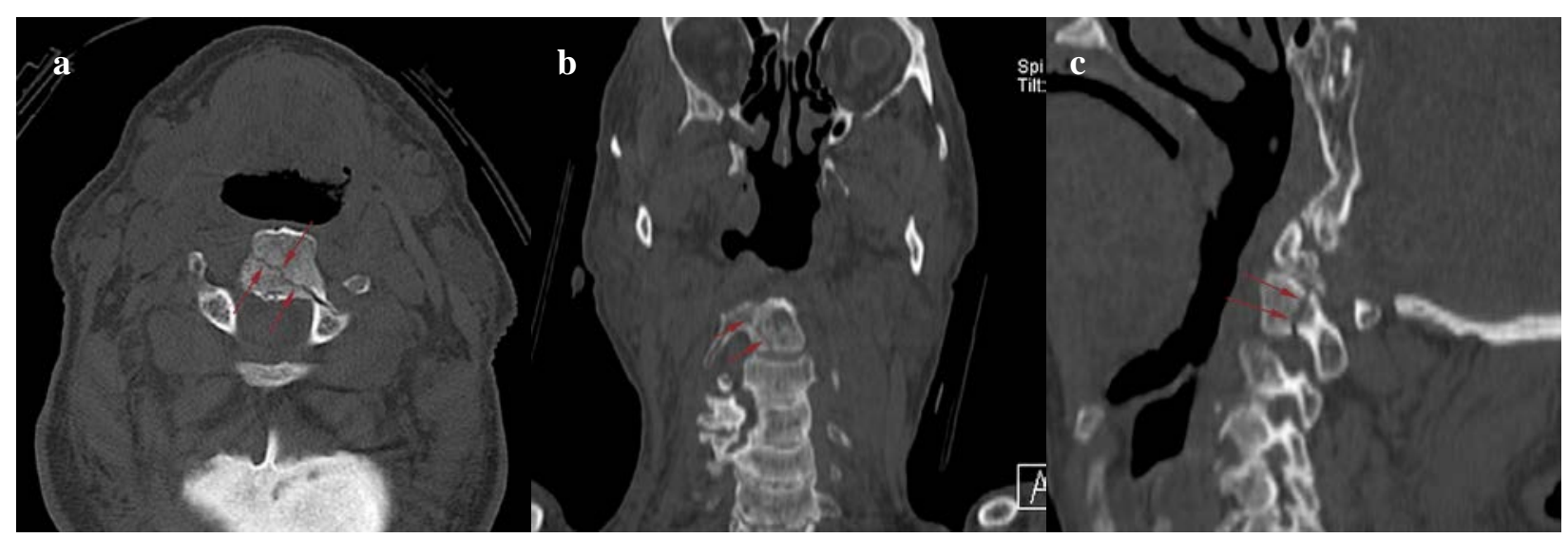

Figure 1: (a) Axial, (b) coronal, and (c) sagittal CT images show a non-deplaced corpus fracture of the second cervical vertebrae.
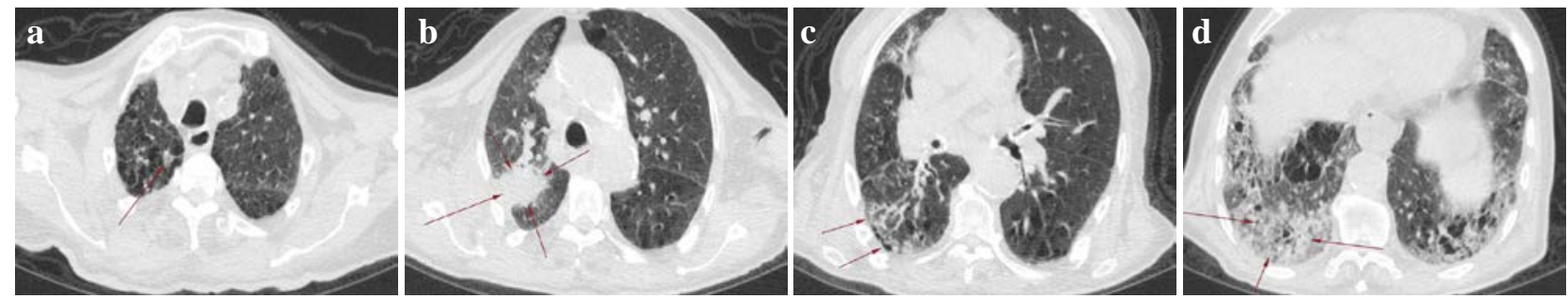

Figure 2: (a) Axial CT scan images of the patient showed bilateral ground-glass opacities and consolidations: nodular opacity, (b) peripheral mass in right superior lobe, (c) reticular pattern with air bubble sign and (d) air bronchogram, reticular pattern superimposed on the background of groundglass opacities and consolidations like crazy paving stones sign.

As antiviral therapy, any treatment has not been approved yet but there are several suggestions such as lopinavir/ritonavir (400/100 mg). However, i t is not found beneficial compared to standard care through a recent randomized, controlled, open-label trial (13). An RNA polymerase inhibitor drug, favipiravir which is effective against influenza and Ebola virus infection is one of the options. A multicenter study demonstrated that favipiravir has effective results compared to umifenovir (14). For the high risk of thromboembolism in COVID-19 patients' anticoagulation like enoxaparin is necessary during therapy (15).

We applied standard therapy according to our guideline provided by the Turkish Ministry of Health compatible with these reports. Additionally, we gave antibiotics because of high procalcitonin levels against secondary bacterial infections.
In a study with COVID-19 patients admitted to the intensive care unit in the area of Seattle the most common symptoms were shortness of breath and cough, the frequency of fever on admission was $50 \%$, and the rate patients with a history of diabetes mellitus were $58 \%$. Also, the main reason for ICU hospitalization was hypoxemic respiratory failure and hypotension (16). Our case mostly has similar clinical features.

In conclusion, even patients without a history of close contact with confirmed COVID-19 cases or travel/having been a resident of pandemic areas and apparent symptoms could have COVID-19 disease. So, during the pandemic period, every patient must be assumed to have the disease and necessary preventive measures must be taken.

\section{Conflicts of Interest}

The authors have no conflicts of interest to declare.

\section{REFERENCES}

1. Wu F, Zhao S, Yu B, Chen YM, Wang W, Song ZG, et al. A new coronavirus associated with human respiratory disease in China. Nature 2020;579:265-269.

2. Velavan TP and Meyer CG. The COVID-19 epidemic. Trop. Med. Int. Health. 2020;25(3):278-280.

3. Lai C, Shih T, Ko WC, Tang HJ, Hsueh PR. Severe acute respiratory syndrome coronavirus2 (SARS-CoV-2) and coronavirus disease-2019 (COVID-19): The epidemic and the challenges. Int. J. Antimicrob. Agents. 2020;55:1-9.

4. Zu ZY, Jiang MD, Xu PP, Chen W, Ni QQ, Lu GM, et al. Coronavirus disease 2019 (COVID-19): a perspective from China. Radiology. 2020;296:E15-E25.

5. Chen N, Zhou M, Dong X, Qu J, Gong F, Han Y, et al. Epidemiological and clinical characteristics of 99 cases of 2019 novel coronavirus pneumonia in Wuhan, China: a descriptive study. Lancet 2020;395:391-393.

6. Shi H, Han X, Jiang N, Cao Y, Alwalid O, Gu J, et al. Radiological findings from 81 patients with COVID-19 pneumonia in Wuhan, China: a descriptive study. Lancet. 2020;20:425-434. 
7. Kong W and Agarwal PP. Chest Imaging appearance of COVID-19. Infection. 2020;2(1):1-22.

8. Fang Y, Zhang H, Xie J, Lin M, Ying L, Pang P, et al. Sensitivity of chest CT for COVID-19: comparison to RT-PCR. Radiology. 2020;296(2):E115-117.

9. Wu Z. and McGoogan JM. Characteristics of and important lessons from the coronavirus disease 2019 (COVID-19) Outbreak in China Chinese Center for Disease Control and Prevention, Beijing, China. JAMA. 2020: E1-4.

10. Xu Z, Shi L, Wang Y, Zhang J, Huang L, Zhang C, et al. Pathological findings of COVID-19 associated with acute respiratory distress syndrome. Lancet Respir Med. 2020:1-3.

11. Zhang L, Yan X, Fan Q, Liu H, Liu X, Liu Z, et al. D-dimer levels on admission to predict in-hospital mortality in patients with COVID-19. J Thromb Haemost. 2020;18:1324-1329.

12. Gautret P, Lagier JC, Parola P, Colson P, Cortaredona S, Giraud-Gatineau A, et al. Hydroxychloroquine and azithromycin as a treatment of COVID-19: results of an open-label non-randomized clinical trial. Int. J. Antimicrob. Agents. 2020;56(1):1-6.

13. Cao B, Wang Y, Wen D, Liu W, Wang J, Fan G, et al. A trial of lopinavir-ritonavir in adults hospitalized with severe COVID-19. N. Engl. J. Med. 2020;382(19):1787-1799.

14. Chen C, Zhang Y, Huang J, Yin P, Cheng Z, Wu J, et al. Favipiravir versus arbidol for COVID-19: a randomized clinical trial. medRxiv. 2020; doi: 10.1101/2020.03.17.20037432

15. Kollias A, Kyriakoulis KG, Dimakakos E, Poulakou G, Stergiou GS, Syrigos K. Thromboembolic risk and anticoagulant therapy in COVID19 patients: emerging evidence and call for action. Br. J. Haematol. 2020;189(5):846-847.

16. Bhatraju PK, Ghassemieh BJ, Nichols M, Kim R, Jerome KR, Nalla AK, et al. COVID-19 in critically 1 ll patients in the seattle region-case series. N Engl J Med. 2020;382(21):2012-2022. 